\title{
Prognosis of pathogen-proven acute respiratory distress syndrome diagnosed from a protocol that includes bronchoalveolar lavage: a retrospective observational study
}

\author{
Michihito Kyo* (D), Koji Hosokawa, Shinichiro Ohshimo, Yoshiko Kida, Yuko Tanabe and Nobuaki Shime
}

\begin{abstract}
Background: To treat patients with acute respiratory distress syndrome (ARDS), it is important to diagnose specific lung diseases and identify common risk factors. Our facility focuses on using bronchoalveolar lavage (BAL) to identify precise risk factors and determine the causative pathogen of ARDS within $24 \mathrm{~h}$ of intensive care unit (ICU) admission. This study evaluated the prognoses of pathogen-proven ARDS patients who were diagnosed or identified with risk factors using a diagnostic protocol, which included BAL, compared with the prognoses of pathogen-unproven ARDS patients.

Methods: This retrospective observational study was conducted in the ICU at a tertiary hospital from October 2015 to January 2019. We enrolled patients with respiratory distress who were on mechanical ventilation for more than $24 \mathrm{~h}$ in the ICU and who were subjected to our diagnostic protocol. We compared the disease characteristics and mortality rates between pathogen-proven and pathogen-unproven ARDS patients.

Results: Seventy ARDS patients were included, of whom, 50 (71\%) had pathogen-proven ARDS as per our protocol. Mortality rates in both the ICU and the hospital were significantly lower among pathogen-proven ARDS patients than among pathogen-unproven ARDS patients (10\% vs. 50\%, $p=0.0006 ; 18 \%$ vs. $55 \%, p=0.0038$, respectively). Pathogen-proven ARDS patients were independently associated with hospital survival (adjusted hazard ratio, 0.238; 95\% confidence interval, 0.096-0.587; $p=0.0021$ ).

Conclusions: Our diagnostic protocol, which included early initiation of BAL, enabled diagnosing pathogen-proven ARDS in 71\% of ARDS patients. These patients were significantly associated with higher hospital survival rates. The diagnostic accuracy of our diagnostic protocol, which includes BAL, remains unclear.
\end{abstract}

Keywords: Pneumonia, BAL, Mimicker, Common risk factor, ARDS, Sepsis, ICU

\footnotetext{
* Correspondence: mkyo@hiroshima-u.ac.jp

Department of Emergency and Critical Care Medicine, Graduate School of Biomedical and Health Sciences, Hiroshima University, 1-2-3 Kasumi,

Minami-ku, Hiroshima 734-8551, Japan
}

(c) The Author(s). 2020 Open Access This article is licensed under a Creative Commons Attribution 4.0 International License, which permits use, sharing, adaptation, distribution and reproduction in any medium or format, as long as you give appropriate credit to the original author(s) and the source, provide a link to the Creative Commons licence, and indicate if changes were made. The images or other third party material in this article are included in the article's Creative Commons licence, unless indicated otherwise in a credit line to the material. If material is not included in the article's Creative Commons licence and your intended use is not permitted by statutory regulation or exceeds the permitted use, you will need to obtain permission directly from the copyright holder. To view a copy of this licence, visit http://creativecommons.org/licenses/by/4.0/ The Creative Commons Public Domain Dedication waiver (http://creativecommons.org/publicdomain/zero/1.0/) applies to the data made available in this article, unless otherwise stated in a credit line to the data. 


\section{Background}

Acute respiratory distress syndrome (ARDS) is a lifethreatening disease with a mortality rate of $~ 40 \%$ [1]. The Berlin definition defines ARDS as respiratory distress occurring within 7 days of recognizing a common risk factor [2]. However, some patients are diagnosed with ARDS based on pathophysiological parameters but without a proven etiology or causative pathogen [3]. Thus, studies examining ARDS often include heterogeneous syndromes as well as ARDS mimickers [4].

The bronchoalveolar lavage (BAL) examination is used to differentially diagnose respiratory diseases, including ARDS. One study found that of ARDS patients who underwent BAL, $56 \%$ presented microbial pathogens and were definitively diagnosed with pneumonia, the leading risk factor for ARDS [5]. Therefore, BAL enables performing successful definitive therapy and reduces mortality from ARDS. Gibelin et al. reported that ARDS patients without common risk factors were diagnosed with autoimmune and malignant diseases via BAL examination, and these patients were associated with higher mortality risks [6]. BAL was recently recommended as a method for identifying the ARDS etiology and distinguishing interstitial pneumonia from ARDS $[3,7,8]$. However, the secondary analysis of the LUNG SAFE study revealed that only 9\% of ARDS patients underwent BAL [9].

Our facility focuses on diagnosing lung diseases, differentiating interstitial pneumonia, and identifying the ARDS etiology using BAL. Furthermore, we started a protocol for diagnosing or identifying ARDS etiologies via sputum culture, gene analysis, serum testing, BAL analysis, and computed tomography (CT) scans in 2015. This study compared the prognoses of ARDS patients with or without proven causative pathogen using our diagnostic protocol, which includes BAL.

\section{Methods}

\section{Study design and population}

This observational study was conducted in the emergency and medical intensive care units (ICUs) of Hiroshima University Hospital from October 2015 to January 2019. The Institutional Review Board of Hiroshima University approved the study protocol (trial registration: E-1751, registered on 17 September 2019).

We retrospectively reviewed the medical records of ICU patients with respiratory failure at admission and included consecutive patients (aged $\geq 18$ years) who were considered to have ARDS from pathophysiological parameters and stayed in the ICU for more than $24 \mathrm{~h}$. Clinically defined ARDS was diagnosed and categorized as mild, moderate, or severe according to the Berlin definition. Patients with respiratory distress of unknown etiology were included. Patients who were postoperative or non-medical (including trauma and burns) admission, had interstitial pneumonia, or had do-not-resuscitate orders were excluded.

\section{Diagnostic protocol}

All ARDS patients underwent chest X-rays and CT scans at the timing of diagnosing ARDS if their condition allowed it. After patients were intubated, BAL was performed to determine the ARDS etiologies and causative pathogens. For the BAL procedure, $100-150 \mathrm{~mL}$ of normal saline was injected into the wedged bronchi, where a lobar infiltrate was observed on chest $\mathrm{CT}$ scans, and gently suctioned. The BAL fluid (BALF) was rapidly Gram-stained, cultured, and underwent cytological analysis on a weekday. When Gram staining of the BALF revealed no microorganisms, the BALF was analyzed via polymerase chain reaction (PCR) for Mycobacterium spp. and Mycoplasma pneumoniae, and Loop-mediated isothermal amplification (LAMP) for Legionella pneumophila. Urinary antigen testing was also performed for Streptococcus pneumonia and Legionella pneumophila. For immunosuppressed patients, we measured the serum beta-D-glucan, analyzed the BALF for the Aspergillus antigen, and performed PCR for Pneumocystis carinii and cytology and C7-HRP to detect Cytomegalovirus spp. During the regional epidemic season, reversetranscription PCR was performed on the BALF to test for the influenza virus. When causative pathogens were not identified or the precise cause of ARDS could not be determined, we further analyzed the BAL cell differentials to determine the etiology of ARDS, and this sometimes revealed evidence of interstitial pneumonia. However, potential pathogens were only identified during the initial analysis of the BAL fluid in the present study.

Immunological testing, including laboratory tests for proteinase-3-anti-neutrophil cytoplasmic antibodies (ANCA), myeloperoxidase-ANCA, anti-basement membrane antibody, and antinuclear antibody, were also performed.

\section{Definition}

ARDS etiology was determined via a diagnostic protocol, which included BAL. Pathogen-proven ARDS was defined according to the following risk factors: (1) pneumonia with an identified causative pathogen, (2) nonpulmonary sepsis with an identified causative pathogen, and (3) aspiration pneumonia. Pneumonia was diagnosed from at least one of the following: body temperature $>38.0^{\circ} \mathrm{C}$; white blood cell count $>12,000 /$ $\mathrm{mm}^{3}$ or $<4000 / \mathrm{mm}^{3}$; altered mental status; and a positive microbial culture including bacteria, fungi, and/or a virus [10], in addition to new regional or lobar 
infiltration on chest radiographs and CT scans. Nonpulmonary sepsis was diagnosed as an increased Sequential Organ Failure Assessment (SOFA) score of $\geq 2$ points and identification of an infectious source other than the lungs. Aspiration pneumonia was diagnosed on the basis of a characteristic clinical history (witnessed aspiration), the presence of risk factors (lower level of consciousness, an impaired cough reflux or impaired swallowing), and radiographic findings, including the presence of infiltrates in gravity-dependent lung segments [11].

\section{Management}

The ventilator management was lung protective ventilation. Patients with partial pressure of arterial oxygen $\left(\mathrm{PaO}_{2}\right)$ /fraction of inspiratory oxygen $\left(\mathrm{F}_{\mathrm{I}} \mathrm{O}_{2}\right)$ ratio $<100$ were considered using neuromuscular blockage, initiating prone positioning and veno-venous extracorporeal membrane oxygenation (ECMO) which were performed for some but not all patients. Veno-venous ECMO was initiated according to the findings of the CESAR trial [12], i.e., when the Murray score (derived from all four variables: $\mathrm{PaO}_{2} / \mathrm{FIO}_{2}$ ratio, positive end-expiratory pressure, lung compliance, and chest radiographic appearance; and when $\mathrm{FIO}_{2}=1$ ) was $\geq 3.0$ or the $\mathrm{pH}$ was $<7.20$, or the patient did not respond to protective lung ventilation and prone positioning $\left(\mathrm{SaO}_{2}<\right.$ $90 \%$ or $\mathrm{pH}<7.20)$.

\section{Data collection}

We collected demographic data, including age, sex, past illness history, SOFA score, Acute Physiology and Chronic Health Evaluation (APACHE) II score, and ARDS severity upon ICU admission. We also recorded the lowest $\mathrm{PaO}_{2} /$ $\mathrm{F}_{\mathrm{I}} \mathrm{O}_{2}$ ratio, tidal volume, ventilator parameters, and ARDS therapy used (e.g., neuromuscular-blocking agents, corticosteroid therapy, initiation of prone positioning, hemodialysis, ECMO, and tracheostomy). The clinical outcomes were ventilator management duration, length of the hospital and ICU stays, and mortality.

\section{Statistical analysis}

Values are presented as medians (interquartile range; IQR) or numbers (percentage) as appropriate. Categorical variables were compared between pathogen-proven and pathogen-unproven ARDS patients using Fisher's exact tests. Continuous variables were compared using Mann-Whitney $U$ tests. Cox regression analysis was performed to assess the pathogen-proven ARDS relative to hospital mortality, and the results are shown as hazard ratios. Factors with $p$ value $<0.05$ in the univariate analyses and pathogen-proven ARDS were entered into the multivariate model. All statistical analyses were conducted using the JMP statistical software (version 14.0.0; SAS, Cary, NC, USA).

\section{Results}

\section{Prevalence of pathogen-proven ARDS}

In total, 1446 patients were intubated, of which, 109 met the Berlin definition of ARDS and stayed in the ICU for more than $24 \mathrm{~h}$. Finally, 70 ARDS patients who met the inclusion criteria were analyzed (Fig. 1). Fifty patients (71\%) had pathogen-proven ARDS as per the diagnostic protocol that included BAL.

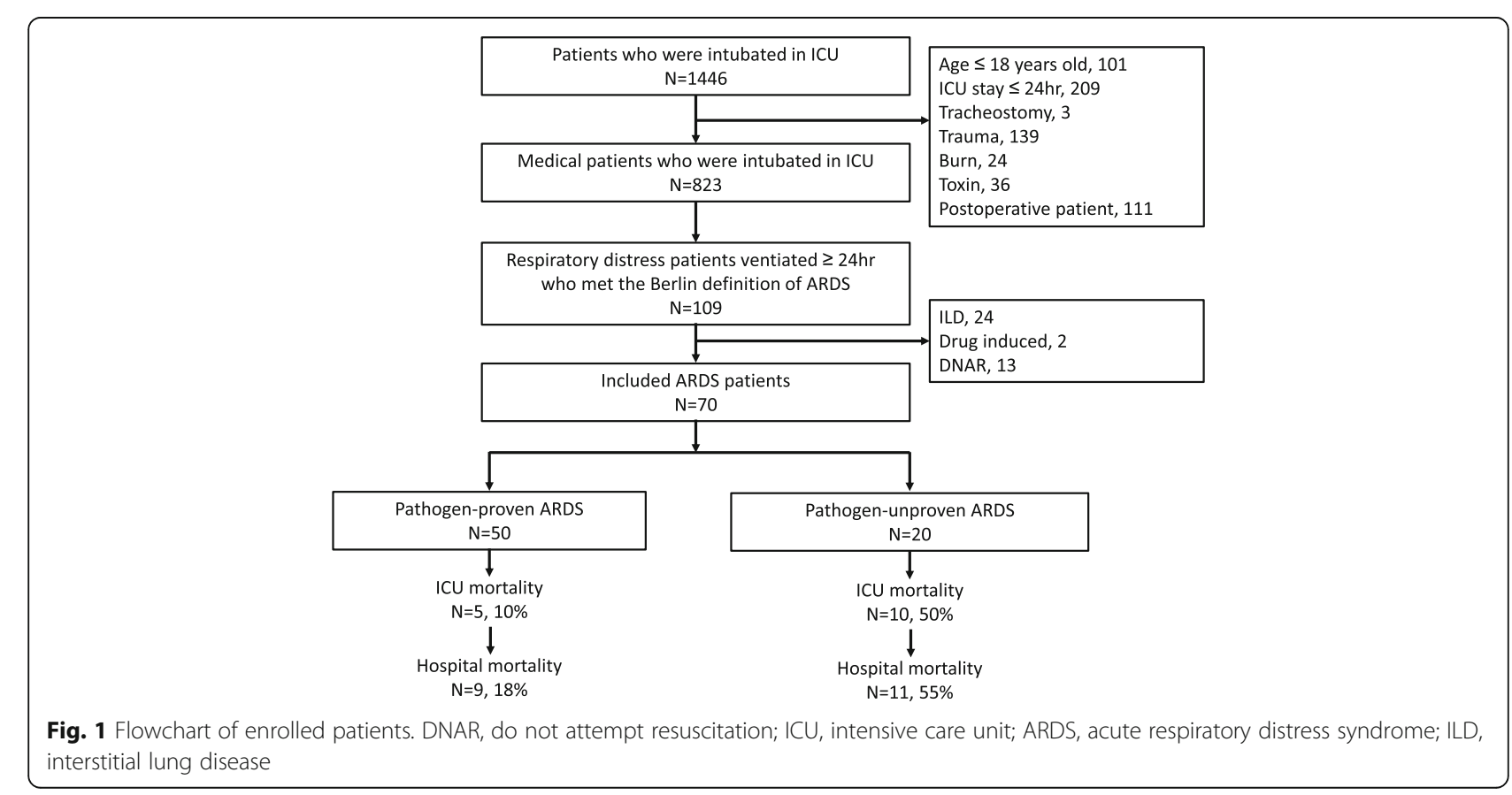




\section{ARDS patient characteristics}

Table 1 shows the patients' baseline characteristics. The median age was 66 years (range, $57-74$ years), and 42 patients (61\%) were men. The median SOFA score was 11 (9-13); the median APACHE II score was 28 (24-32). In this cohort, age, SOFA score, APACHE II score, ARDS severity, and mechanical ventilation parameters did not

Table 1 Patient characteristics and ventilator parameters on the day of admission

\begin{tabular}{|c|c|c|c|c|}
\hline & $\begin{array}{l}\text { All } \\
\text { patients } \\
(\boldsymbol{n}=70)\end{array}$ & $\begin{array}{l}\text { Pathogen- } \\
\text { proven ARDS } \\
\text { group } \\
(\boldsymbol{n}=50)\end{array}$ & $\begin{array}{l}\text { Pathogen- } \\
\text { unproven } \\
\text { ARDS group } \\
(\boldsymbol{n}=20)\end{array}$ & $p$ \\
\hline Age, year & $66(57-73)$ & $67(59-74)$ & $60(43-71)$ & 0.097 \\
\hline Male & $43(61)$ & $32(64)$ & $11(55)$ & 0.589 \\
\hline SOFA score & $11(9-13)$ & $11(9-13)$ & $11(10-13)$ & 0.700 \\
\hline APACHE II score & $29(24-32)$ & $29(24-32)$ & $28(25-31)$ & 0.745 \\
\hline $\begin{array}{l}\text { Transferred from } \\
\text { other hospital }\end{array}$ & $26(37)$ & $21(42)$ & $5(25)$ & 0.274 \\
\hline $\begin{array}{l}\text { Prior use of } \\
\text { antibiotics }\end{array}$ & $29(41)$ & $18(36)$ & $11(55)$ & 0.183 \\
\hline \multicolumn{5}{|l|}{ Comorbidities } \\
\hline Heart failure & $1(1)$ & $0(0)$ & $1(5)$ & 0.286 \\
\hline Stroke & $6(9)$ & $5(10)$ & $1(5)$ & 0.666 \\
\hline COPD & $7(10)$ & $4(8)$ & $3(15)$ & 0.399 \\
\hline Renal failure & $6(9)$ & $3(6)$ & $3(15)$ & 0.343 \\
\hline Malignancy & $16(23)$ & $13(26)$ & $3(15)$ & 0.529 \\
\hline Liver failure & $19(27)$ & $14(28)$ & $5(25)$ & 1.000 \\
\hline Immunosuppression & $17(24)$ & $11(22)$ & $6(30)$ & 0.543 \\
\hline $\begin{array}{l}\text { Severity of ARDS } \\
\text { (Berlin definition) }\end{array}$ & & & & 0.620 \\
\hline Mild & $10(14)$ & $6(12)$ & $4(20)$ & \\
\hline Moderate & $35(47)$ & $27(50)$ & $8(40)$ & \\
\hline Severe & $27(39)$ & $19(38)$ & $8(40)$ & \\
\hline \multicolumn{5}{|l|}{ Mechanical ventilation } \\
\hline $\mathrm{PaO}_{2} / \mathrm{F}_{1} \mathrm{O}_{2}$ & $\begin{array}{l}127 \\
(85-179)\end{array}$ & $\begin{array}{l}127 \\
(82-176)\end{array}$ & $\begin{array}{l}135 \\
(96-196)\end{array}$ & 0.413 \\
\hline $\mathrm{F}_{1} \mathrm{O}_{2}$ & $\begin{array}{l}0.60 \\
(0.40-0.76)\end{array}$ & $\begin{array}{l}0.60 \\
(0.45-0.80)\end{array}$ & $\begin{array}{l}0.53 \\
(0.40-0.74)\end{array}$ & 0.377 \\
\hline PEEP & $11(8-14)$ & $10(8-14)$ & $12(10-14)$ & 0.155 \\
\hline Driving pressure & $13(10-16)$ & $12(10-14)$ & $14(10-16)$ & 0.483 \\
\hline TV & $\begin{array}{l}455 \\
(389-529)\end{array}$ & $\begin{array}{l}460 \\
(397-524)\end{array}$ & $\begin{array}{l}455 \\
(364-550)\end{array}$ & 0.716 \\
\hline TV/PBW & $8.0(7.0-9.4)$ & $8.0(7.0-10.0)$ & $8.0(7.1-9.2)$ & 0.721 \\
\hline Septic shock & $26(37)$ & $24(48)$ & $2(10)$ & 0.003 \\
\hline
\end{tabular}

Values are given as the median (interquartile range) or number (\%). $p$ values were calculated via Fisher's exact test or the Mann-Whitney $U$ test ARDS Acute respiratory distress syndrome, SOFA Sequential Organ Failure Assessment, APACHE Acute Physiology and Chronic Health Evaluation, COPD chronic obstructive pulmonary disease, $\mathrm{PaO}_{2}$ partial pressure of arterial oxygen, $\mathrm{F}_{1} \mathrm{O}_{2}$ fraction of inspiratory oxygen, $P E E P$ positive end-expiratory pressure, $T V$ tidal volume, $P B W$ predicted body weight significantly differ between pathogen-proven and pathogen-unproven ARDS patients.

\section{ARDS etiology}

In the 50 pathogen-proven ARDS patients, pneumonia was the most common risk factor $(n=31)$, followed by sepsis $(n=13)$, and aspiration $(n=6$; Table 2$)$. Of the 31 pneumonia patients, 20 had bacteria, 4 had viruses, 4 had fungi, and 3 had both viruses and fungi in their BAL. Streptococcus pneumonia was predominant $(n=7)$ among the bacterial pneumonia patients. The influenza virus was predominant $(n=6)$ among viral pneumonia patients.

\section{Treatment and outcomes of the ARDS patients}

The treatment options used (e.g., neuromuscularblocking agents, prone positioning, corticosteroid

Table 2 Causative microorganisms of acute respiratory distress syndrome

\begin{tabular}{lll}
\hline$N=50$ & & \\
\hline Pneumonia $(N=31)$ & & 7 \\
Bacteria $(N=20)$ & Streptococcus pneumonia & 2 \\
& MRSA & 4 \\
& Legionella pneumophila & 2 \\
& MSSA & 1 \\
& Klebsiella pneumonia & 1 \\
& Schewanella algae & 1 \\
& Moraxella catarrhalis & 1 \\
& Enterobacter aerogenes & 1 \\
Virus $(N=7)$ & Haemophilus influenza & 3 \\
& Influenza virus & 3 \\
& Cytomegalovirus & 1
\end{tabular}

Aspiration $(N=6)$

Sepsis $(N=13)$

$\begin{array}{ll}\text { Streptococcus pyogenes } & 4 \\ \text { Escherichia coli } & 3 \\ \text { MRSA } & 2 \\ \text { Peptostreptococcus spp., prevotella oralis } & 1 \\ \text { Morganella morganii } & 1 \\ \text { Klebsiella pneumonia } & 1 \\ \text { Klebsiella oxytoca } & 1 \\ \text { Leptotrichia trevisanii } & 1\end{array}$

Aspergillus spp. in pneumonia patients and Escherichia coli in sepsis patients were duplicated. Of the 31 patients with pneumonia, three had both viruses and fungi as causative pathogens

MRSA methicillin-resistant Staphylococcus aureus, MSSA methicillin-sensitive Staphylococcus aureus 
therapy, and veno-venous ECMO initiation) did not significantly differ between the groups (Table 3 ). The ICU-free days during a 28-day period in the pathogenproven ARDS group was significantly longer than in the pathogen-unproven ARDS group (13 [5-16] vs. 1 [015 ], $p=0.034)$. The overall ICU mortality rate was $21 \%$; the hospital mortality rate was $29 \%$. The ICU and hospital mortality rates were significantly lower in ARDS patients with identified etiologies (10\% vs. $50 \%, p=$ $0.0006 ; 18 \%$ vs. $55 \%, p=0.0038$, respectively).

\section{Factors associated with hospital mortality}

Univariate analyses showed that pathogen-proven ARDS (hazard ratio [HR], 0.265; 95\% confidence interval [CI], 0.109-0.647; $p=0.004$ ) and higher SOFA scores (HR, $1.211 ; 95 \%$ CI, 1.068-1.374; $p=0.0028$ ) were significantly associated factors with hospital mortality (Table 4). Pathogen-proven ARDS was significantly associated with hospital mortality after adjusting for SOFA score (HR, 0.238; 95\% CI, 0.096-0.587; $p=0.0021$ ).

\section{Discussion}

In the present study, $71 \%$ of ARDS patients had pathogen-proven ARDS. To our knowledge, this was the first study to investigate the prognostic impact of a diagnostic protocol that included BAL in ARDS patients. The hospital mortality rate of pathogen-proven ARDS patients was lower than that of pathogen-unproven patients after adjusting for SOFA scores.

A nationwide survey in Japan revealed that $34 \%$ of ARDS patients had pneumonia, and all ARDS patients had risk factors [13]. Conversely, a survey conducted in the USA from 2006 to 2014 revealed that approximately $45 \%$ of ARDS patients had pneumonia, and $16 \%$ had no specific risk factors [14]. The discrepancy between these findings may have occurred because of the ambiguous diagnosis of ARDS risk factors, which depends on BAL for detecting microorganisms that cause pneumonia or the vague clinical criteria for pneumonia. In our setting, BAL-based detection systems, especially LAMP for Legionella pneumophila and PCR for Pneumocystis jirovecii, influenza viruses, and cytomegaloviruses, contributed to detecting many causative organisms. This is consistent with the findings of previous studies and supports aggressively using BAL to increase the ability to diagnose pneumonia as an ARDS etiology [15-17].

The reduced mortality of pathogen-proven ARDS patients in this study may be explained as follows. First, ARDS patients with no common risk factors included those with autoimmune and idiopathic diseases, and the absence of common risk factors has been associated with increased mortality in ICUs $[6,18]$. Second, the outcomes (i.e., development of acute lung injury/ARDS or mortality) of patients with infections can be improved via early and appropriate antimicrobial therapy [19-21]. In addition, precise detection of microorganisms shortens the duration of empiric antibiotic therapy [22], resulting in fewer adverse events. Given the overall low performance of BAL $(9.4 \%)$ in a large-scale epidemiological study (LUNG SAFE study) [9], BAL-based diagnostic approaches should be more widely applied for ARDS patients to help improve their outcomes.

Table 3 Therapy and outcome

\begin{tabular}{|c|c|c|c|c|}
\hline & $\begin{array}{l}\text { All patients } \\
(\boldsymbol{N}=70)\end{array}$ & $\begin{array}{l}\text { Pathogen-proven } \\
\text { ARDS group }(\boldsymbol{N}=50)\end{array}$ & $\begin{array}{l}\text { Pathogen-unproven } \\
\text { ARDS group }(\boldsymbol{N}=20)\end{array}$ & $p$ \\
\hline \multicolumn{5}{|l|}{ Therapy } \\
\hline Neuromuscular blocking agents & $12(17)$ & $8(16)$ & $4(20)$ & 0.732 \\
\hline Corticosteroid therapy & $29(41)$ & $20(40)$ & $9(45)$ & 0.791 \\
\hline Prone position & $5(7)$ & $3(6)$ & $2(10)$ & 0.619 \\
\hline Hemodialysis & $21(30)$ & $15(30)$ & $6(30)$ & 1.000 \\
\hline VA ECMO & $5(7)$ & $4(8)$ & $1(5)$ & 1.000 \\
\hline W ECMO & $12(17)$ & $11(22)$ & $1(5)$ & 0.158 \\
\hline Tracheostomy & $28(40)$ & $20(40)$ & $8(40)$ & 1.000 \\
\hline Appropriate antibiotic therapy for causative pathogens within day 3 & - & $48(96)$ & - & - \\
\hline \multicolumn{5}{|l|}{ Outcome } \\
\hline Ventilator-free days of 28 days & $16(0-20)$ & $18(7-20)$ & $4(0-22)$ & 0.112 \\
\hline ICU-free days of 28 days & $13(0-16)$ & $13(5-16)$ & $1(0-15)$ & 0.034 \\
\hline ICU mortality & $15(21)$ & $5(10)$ & $10(50)$ & 0.0006 \\
\hline Hospital-free days of 28 days & $0(0-6)$ & $0(0-6)$ & $0(0-7)$ & 0.613 \\
\hline Hospital mortality & $20(29)$ & $9(18)$ & $11(55)$ & 0.0038 \\
\hline
\end{tabular}

Values are given as the median (interquartile range) or number (\%). $p$ values were calculated using Fisher's exact test or the Mann-Whitney $U$ test $A R D S$ acute respiratory distress syndrome, VA ECMO veno-arterial extracorporeal membrane oxygenation, $V V$ veno-venous, ICU intensive care unit 
Table 4 Univariate and multivariate analyses of factors associated with hospital survival

\begin{tabular}{|c|c|c|c|c|c|c|}
\hline Variables & Univariable HR & $95 \% \mathrm{Cl}$ & $p$ & Multivariable HR & $95 \% \mathrm{Cl}$ & $p$ \\
\hline Pathogen-proven ARDS & 0.265 & $0.109-0.647$ & 0.004 & 0.238 & $0.096-0.587$ & 0.0021 \\
\hline Age (per year decrease) & 0.974 & $0.942-1.008$ & 0.126 & & & \\
\hline Male & 0.751 & $0.302-1.869$ & 0.542 & & & \\
\hline SOFA score (per 1 increase) & 1.211 & $1.068-1.374$ & 0.0028 & 1.226 & $1.082-1.390$ & 0.0015 \\
\hline APACHEllscore (per 1 increase) & 1.030 & $0.966-1.101$ & 0.363 & & & \\
\hline $\mathrm{PaO}_{2} / \mathrm{F}_{1} \mathrm{O}_{2}$ & 1.014 & $0.940-1.090$ & 0.715 & & & \\
\hline COPD & 1.941 & $0.560-6.730$ & 0.332 & & & \\
\hline Liver failure & 1.869 & $0.762-4.586$ & 0.184 & & & \\
\hline Corticosteroids & 1.164 & $0.478-2.830$ & 0.739 & & & \\
\hline Hemodialysis & 2.356 & $0.956-5.806$ & 0.069 & & & \\
\hline W ECMO & 0.834 & $0.243-2.867$ & 0.769 & & & \\
\hline
\end{tabular}

HR hazard ratio, $\mathrm{Cl}$ confidence interval, ARDS acute respiratory distress syndrome, SOFA Sequential Organ Failure Assessment, APACHE Acute Physiology and Chronic Health Evaluation, COPD chronic obstructive pulmonary distress, VV ECMO veno-venous extracorporeal membrane oxygenation

This study had several limitations. First, it was a single-center, retrospective observational study of relatively few patients. In addition, the etiology of the pathogen-unproven ARDS was not determined (Supplementary Table 1). We excluded potential participants with several major ARDS etiologies (e.g., burn, trauma, and drug-induced) and other etiologies (e.g., interstitial pneumonia). Analysis of the BAL fluid revealed no significant pathogens in the pathogen-unproven ARDS patients, and they also did not have non-septic shock or other significant risk factors, such as transfusion or pancreatitis. However, this group could have included "ARDS mimickers" as defined in a previous study [3] and hematological malignancy-related ARDS. The survival rate of ARDS mimickers and hematological malignancy-related ARDS is poor [23], which may explain the poor outcomes in the pathogen-unproven ARDS cohort in the present study, even though there were fewer patients with septic shock in this group. Further studies are required to investigate the clinical characteristics of these subtypes of ARDS. Second, our hospital is a tertiary hospital, and $37 \%$ of our patients were transported from other hospitals after antibiotic administration, which may differ among settings. Third, the selection of wedged bronchi for BAL might have affected the sensitivity of pathogen detection. Fourth, regarding viruses, we only tested for cytomegaloviruses and influenza viruses. Therefore, presence of other causative viruses, such as rhinoviruses, adenoviruses, and herpesviruses, is unknown. Applications of currently available, easy-to-use, comprehensive, molecular-based diagnostic systems, such as Fillmarray ${ }^{\mathrm{TM}}$, would help increase pathogen detection rates and enable faster treatment, especially for viruses [24]. In addition, we included patients who were on mechanical ventilation for more than $24 \mathrm{~h}$; thus, some severely ill patients may have been excluded, affecting the mortality analysis. Finally, the definition of "pathogen-unproven ARDS" has not been standardized and may include ARDS "mimickers" [3]. However, the definition of ARDS "mimickers" has also not been standardized. These two terms should be precisely defined to accurately categorize the heterogeneity of ARDS.

\section{Conclusion}

Pathogen-proven ARDS patients who were diagnosed via diagnostic work-up that included BAL had lower mortality rates than did pathogen-unproven ARDS patients. Pathogen-unproven ARDS was significantly associated with hospital mortality. The diagnostic accuracy and significance for treatment of the diagnostic protocol, including BAL, should be determined in further studies.

\section{Supplementary information}

Supplementary information accompanies this paper at https://doi.org/10. 1186/s40560-020-00469-w.

Additional file 1: Table S1. Etiologies of pathogen-unproven ARDS ( $n=20)$.

\begin{abstract}
Abbreviations
ANCA: Anti-neutrophil cytoplasmic antibodies; APACHE: Acute Physiology and Chronic Health Evaluation; ARDS: Acute respiratory distress syndrome; BAL: Bronchoalveolar lavage; BALF: Bronchoalveolar lavage fluid; Cl: Confidence interval; $C \mathrm{CT}$ : Computed tomography; ECMO: Extracorporeal membrane oxygenation; $\mathrm{F}_{1} \mathrm{O}_{2}$ : Fraction of inspiratory oxygen; HR: Hazard ratio; LAMP: Loop-mediated isothermal amplification; $\mathrm{PaO}_{2}$ : Partial pressure of arterial oxygen; PCR: Polymerase chain reaction; SOFA: Sequential Organ Failure Assessment
\end{abstract}

Acknowledgements

We are grateful for all ICU staff of Hiroshima University Hospital. We also thank Traci Raley, MS, ELS, and Mark Cleasby, PhD from Edanz Group (www. edanzediting.com/ac) for editing a draft of this manuscript. 


\section{Authors' contributions}

MK drafted the manuscript. MK collected the data. KH, SO, KY, YT, and NS helped to draft the manuscript. MK and NS participated in the design of the study and revised the manuscript. All authors read and approved the final manuscript

\section{Funding}

This work was supported by KAKENHI grants from the Japan Society for the Promotion of Science (JSPS) (numbers JP 18 K16518, 17 K17053).

\section{Availability of data and materials}

The datasets used and/or analyzed during the current study are available from the corresponding author on reasonable request.

\section{Ethics approval and consent to participate}

The institutional review boards in Hiroshima University (trial registration: E1751, registered on 17 September 2019) approved an opt-out method of informed consent.

\section{Consent for publication}

Not applicable

\section{Competing interests}

Nothing to declare

Received: 27 April 2020 Accepted: 15 July 2020

Published online: 23 July 2020

\section{References}

1. Bellani G, Laffey JG, Pham T, Fan E, Brochard L, Esteban A, et al. Epidemiology, patterns of care, and mortality for patients with acute respiratory distress syndrome in intensive care units in 50 countries. JAMA. 2016;315:788-800

2. Force ADT, Ranieri VM, Rubenfeld GD, Thompson BT, Ferguson ND, Caldwell $E$, et al. Acute respiratory distress syndrome: the Berlin definition. JAMA. 2012:307:2526-33.

3. Aublanc M, Perinel S, Guerin C. Acute respiratory distress syndrome mimics: the role of lung biopsy. Curr Opin Crit Care. 2017;23:24-9.

4. Guerin C, Thompson T, Brower R. The ten diseases that look like ARDS Intensive Care Med. 2015:41:1099-102.

5. Kao KC, Chiu LC, Hung CY, Chang CH, Yang CT, Huang CC, et al. Coinfection and mortality in pneumonia-related acute respiratory distress syndrome patients with bronchoalveolar lavage: a prospective observational study. Shock. 2017;47:615-20

6. Gibelin A, Parrot A, Maitre B, Brun-Buisson C, Mekontso Dessap A, Fartoukh $M$, et al. Acute respiratory distress syndrome mimickers lacking common risk factors of the Berlin definition. Intensive Care Med. 2016:42:164-72.

7. Papazian L, Calfee CS, Chiumello D, Luyt CE, Meyer NJ, Sekiguchi H, et al. Diagnostic workup for ARDS patients. Intensive Care Med. 2016:42:674-85.

8. Meyer KC, Raghu G, Baughman RP, Brown KK, Costabel U, du Bois RM, et al. An official American Thoracic Society clinical practice guideline: the clinical utility of bronchoalveolar lavage cellular analysis in interstitial lung disease. Am J Respir Crit Care Med. 2012;185:1004-14.

9. de Prost N, Pham T, Carteaux G, Mekontso Dessap A, Brun-Buisson C, Fan E, et al. Etiologies, diagnostic work-up and outcomes of acute respiratory distress syndrome with no common risk factor: a prospective multicenter study. Ann Intensive Care. 2017;7:69.

10. Horan TC, Andrus M, Dudeck MA. CDC/NHSN surveillance definition of health care-associated infection and criteria for specific types of infections in the acute care setting. Am J Infect Control. 2008;36:309-32.

11. Mandell LA, Niederman MS. Aspiration pneumonia. N Engl J Med. 2019;380: 651-63.

12. Peek GJ, Mugford M, Tiruvoipati R, Wilson A, Allen E, Thalanany MM, et al. Efficacy and economic assessment of conventional ventilatory support versus extracorporeal membrane oxygenation for severe adult respiratory failure (CESAR): a multicentre randomised controlled trial. Lancet. 2009;374: 1351-63.

13. Tasaka S, Tatsumi K. Assembly of Pulmonary C, Lung Injury JIRS. Clinical practice of acute respiratory distress syndrome in Japan: a nationwide survey and scientific evidences. Respir Investig. 2017;55:257-63.
14. Eworuke E, Major JM, Gilbert McClain LI. National incidence rates for acute respiratory distress syndrome (ARDS) and ARDS cause-specific factors in the United States (2006-2014). J Crit Care. 2018;47:192-7.

15. White PL, Backx M, Barnes RA. Diagnosis and management of Pneumocystis jirovecii infection. Expert Rev Anti-Infect Ther. 2017;15:435-47.

16. Writing Committee of the WHOCoCAoPI, Bautista E, Chotpitayasunondh T, Gao Z, Harper SA, Shaw M, et al. Clinical aspects of pandemic 2009 influenza A (H1N1) virus infection. N Engl J Med. 2010;362:1708-19.

17. Lodding IP, Schultz HH, Jensen JU, Kirkby N, Perch M, Andersen C, et al. Cytomegalovirus viral load in bronchoalveolar lavage to diagnose lung transplant associated CMV pneumonia. Transplantation. 2018:102:326-32.

18. Grasselli G, Vergnano B, Pozzi MR, Sala V, D'Andrea G, Scaravilli V, et al. Interstitial pneumonia with autoimmune features: an additional risk factor for ARDS? Ann Intensive Care. 2017;7:98.

19. Roson B, Carratala J, Fernandez-Sabe N, Tubau F, Manresa F, Gudiol F. Causes and factors associated with early failure in hospitalized patients with community-acquired pneumonia. Arch Intern Med. 2004;164:502-8.

20. Kojicic M, Li G, Hanson AC, Lee KM, Thakur L, Vedre J, et al. Risk factors for the development of acute lung injury in patients with infectious pneumonia. Crit Care. 2012;16:R46.

21. Kethireddy S, Bilgili B, Sees A, Kirchner HL, Ofoma UR, Light RB, et al. Culture-negative septic shock compared with culture-positive septic shock: a retrospective cohort study. Crit Care Med. 2018;46:506-12.

22. Bonten MJ, Bergmans DC, Stobberingh EE, van der Geest S, De Leeuw PW, van Tiel FH, et al. Implementation of bronchoscopic techniques in the diagnosis of ventilator-associated pneumonia to reduce antibiotic use. Am 」 Respir Crit Care Med. 1997;156:1820-4.

23. Azoulay E, Lemiale V, Mourvillier B, Garrouste-Orgeas M, Schwebel C, Ruckly $S$, et al. Management and outcomes of acute respiratory distress syndrome patients with and without comorbid conditions. Intensive Care Med. 2018; 44:1050-60.

24. Andrews D, Chetty Y, Cooper BS, Virk M, Glass SK, Letters A, et al. Multiplex $P C R$ point of care testing versus routine, laboratory-based testing in the treatment of adults with respiratory tract infections: a quasi-randomised study assessing impact on length of stay and antimicrobial use. BMC Infect Dis. 2017;17:671

\section{Publisher's Note}

Springer Nature remains neutral with regard to jurisdictional claims in published maps and institutional affiliations.

Ready to submit your research? Choose BMC and benefit from:

- fast, convenient online submission

- thorough peer review by experienced researchers in your field

- rapid publication on acceptance

- support for research data, including large and complex data types

- gold Open Access which fosters wider collaboration and increased citations

- maximum visibility for your research: over $100 \mathrm{M}$ website views per year

At $\mathrm{BMC}$, research is always in progress.

Learn more biomedcentral.com/submission 